\title{
Idiopathic Rhabdomyolysis
}

\author{
D. C. L. SAVAGE, MEHROO FORBES*, and G. W. PEARCE \\ From the Department of Child Health, Dundee University; and the Department of Pathology, Newcastle General \\ Hospital, Newcastle upon Tyne
}

\begin{abstract}
Savage, D. C. L., Forbes, M., and Pearce, G. W. (1971). Archives of Disease in Childhood, 46, 594. Idiopathic rhabdomyolysis. The clinical, biochemical, and pathological findings in 2 children with idiopathic rhabdomyolysis are reported. Hypocalcaemic tetany, a previously unrecognized complication of severe muscle damage, was seen in one child and was associated with hyperphosphataemia and hyperphosphaturia consequent on the rhabdomyolysis. Respiratory distress and an acute tubular necrosis contributed to her eventual death. The second child recovered; an intracellular granular material of unknown nature was seen in his muscle biopsy on electron microscopy.

The literature of idiopathic recurrent rhabdomyolysis occurring in childhood is reviewed.
\end{abstract}

Idiopathic rhabdomyolysis, which may be recurrent, is a rare and potentially lethal disorder of skeletal muscle, not previously recorded in the British paediatric literature. Two forms of the disease have been described: Type I usually preceded by physical exertion, and Type II often associated with mild infections. Both are characterized by rhabdomyolysis and myoglobinuria, and death may result from the immediate hyperkalaemia or later from respiratory muscle paralysis or renal tubular necrosis. The aetiology is unknown and the term probably embraces a number of distinct entities. This paper reports two children with Type II rhabdomyolysis and includes a third child, the sister of one of them, who diedprobably from the same disease.

\section{Case Reports}

Case 1. This $3 \frac{1}{2}$-year-old girl was admitted in November 1964. Previously in excellent health she had had for two days, a mild upper respiratory tract infection. On the morning of admission to hospital she complained on waking of pain in her limbs and there was difficulty in walking. Within an hour she could not move her legs and her general condition deteriorated so rapidly that she appeared moribund.

WBC $25,000 / \mathrm{mm}^{3}$, neutrophil leucocytosis; plasma potassium $6.2 \mathrm{mEq} / 1 . \mathrm{CO}_{2}$ content $18 \mathrm{mEq} / 1$. Plasma urea and other electrolytes were normal; CSF normal

Received 8 March 1971.

^Present address: Congenital Anomalies Research Unit, Departinent of Child Health, University of Sheffield. with glucose $72 \mathrm{mg} / 100 \mathrm{ml}$. Urine contained a trace of sugar and ketones.

The child died shortly after admission to hospital, and death was recorded as being due to diabetic ketosis. At necropsy no abnormality was found; muscle tissue was not examined. In retrospect the CSF glucose level makes this diagnosis untenable and it is probable that this child died from a similar disease to that of her sister (Case 2).

Case 2. This 14-month-old child was admitted in December 1967. Previously in excellent health, she had for a few days a mild upper respiratory tract infection. On the morning of admission she had on waking appeared unwell, and her condition rapidly deteriorated. On examination there was respiratory distress and she was in circulatory failure, with cyanosis of the lips and extremities. No other abnormality was noted.

Chest $x$-ray clear; CSF-no abnormality; Hb $11 \mathrm{~g} /$ $100 \mathrm{ml}$, WBC $20,000 / \mathrm{mm}^{3}$, neutrophil leucocytosis; ESR $7 \mathrm{~mm} / \mathrm{hr}$; plasma urea $45 \mathrm{mg} / 100 \mathrm{ml}$; plasma sodium, potassium, chloride, and $\mathrm{CO}_{2}$ were $131,6 \cdot 3$, 104 , and $17 \mathrm{mEq} / 1$. , respectively. $p \mathrm{H} 7 \cdot 26$; base deficit minus 9; $\mathrm{Pco}_{2} 37 \mathrm{mmHg}$; blood glucose $115 \mathrm{mg} /$ $100 \mathrm{ml}$; ketones positive; plasma cortisol $83.5 \mu \mathrm{g} / 100$ $\mathrm{ml}$. Urine: dark red-brown in colour, chemically positive for blood, glucose, ketones, and protein; SG $1020 ; p \mathrm{H} 5$. On microscopy, numerous fine needle-shaped crystals were present; no cells or bacilli were seen.

It was suspected that the child had a septicaemia with haemolysis and haemoglobinuria. Therapy included intravenous fluids, with immediate correction of the metabolic acidosis, antibiotics, and steroids. By 
evening obvious carpopedal spasm was present. Chvostek's sign was positive and serum calcium $2 \cdot 7$ $\mathrm{mEq} / \mathrm{l}$. Calcium gluconate intravenously lessened but did not eradicate the tetany (Fig. 1).

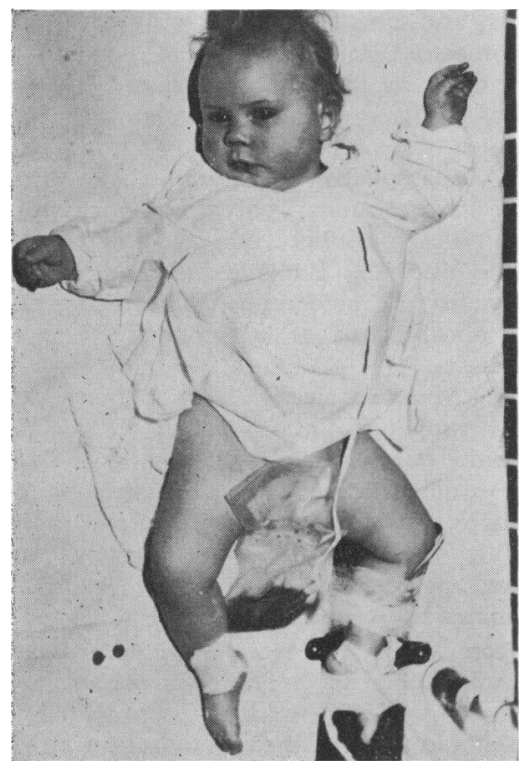

FIG. 1.-Carpopedal spasm and myoglobinuria.

The following morning the urine, now alkaline, was still a dark brown colour; the previously noted needleshaped crystals were no longer present. Investigations: plasma urea $54 \mathrm{mg} / 100 \mathrm{ml}$; plasma sodium, potassium, and $\mathrm{CO}_{2}$ were $138,4 \cdot 6$, and $27 \mathrm{mEq} / \mathrm{l}$., respectively; pH 7. 46; base excess +3; blood glucose $120 \mathrm{mg} / 100 \mathrm{ml}$; serum calcium $3.4 \mathrm{mEq} / \mathrm{l}$; serum phosphate 4.3 $\mathrm{mEq} / \mathrm{l}$; blood culture: sterile. Blood spectroscopy: no abnormality noted. Urine spectroscopy: metmyoglobin and oxymyoglobin detected; haemoglobin not present (Miss J. Bowden). Porphyrins and urobilinogen were absent from the urine.

Now that the urinary pigment was recognized the probable diagnosis appeared to be idiopathic rhabdomyolysis. The following investigations supported this. Serum aspartate aminotransferase 100 units (normal $<40$ units); serum alanine aminotransferase 800 units (normal $<40$ units; aldolase 217 units (normal $<4$ units); lactic dehydrogenase 1730 units (normal $<300$ units); hydroxybutryric dehydrogenase 3600 units (normal $<150$ units); creatine phosphokinase 3500 units (normal $<60$ units). During the first three days urinary amino acids showed an obvious increase in taurine and $\beta$-amino-isobutyric acid (Dr. J. Mellon). Electrophoresis of the urine confirmed the presence of myoglobin (Dr. J. Rae). The muscles, particularly those of the legs and upper arms, were tender and swollen and it was now appreciated that it was because of this that the child lay so still and disliked being touched. Muscle biopsy was taken from the right quadriceps under local anaesthesia 48 hours after admission. The muscle was noted to be extremely pale (Mr. W. A. F. McAdam). Local anaesthesia was used as there are reports of rhabdomyolysis after general anaesthesia (Herzberg, Michener, and Kiser, 1967; Bowden et al., 1956; Haase and Engel, 1960).

Over the next few days there was severe respiratory difficulty. The child's diaphragm appeared paralysed, and respirations were rapid and laboured. In addition there was a generalized and extreme muscle weakness. Throughout this period, though no further myoglobinuria was detected, serum muscle enzymes remained high. On the sixth day of the illness, the serum aldolase was 14 units and the creatine phosphokinase 5800 units. Her fever did not settle and a persistent paralytic ileus necessitated continuous intravenous therapy; apart from a transitory hypokalaemia no further electrolyte or acid-base disturbance occurred.

During the second week of her illness her condition slowly deteriorated. The kidneys became firmly enlarged and macroscopical haematuria developed. On urinary microscopy numerous casts and red blood cells were seen and macroscopical flecks of a brown material, thought to be a mixture of myoglobin, protein, and cellular débris, appeared in her urine. The urinary output remained satisfactory, though the specific gravity became fixed at 1010; slight glycosuria and obvious albuminuria persisted. On the eleventh day of her illness blood and urine cultures grew Escherichia coli. Despite intensive therapy she died suddenly on the fourteenth day of her illness.

No cytopathic agent was found on virus studies of faeces, blood, and CSF.

The parents of these two sisters were not consanguineous and their serum muscle enzymes were normal. There was no known muscle disease on either side of the family and there were no other children in the family.

Case 3. This 7-year-old boy was admitted in March 1968 with a seven-day history of 'influenza'. Two days before admission he complained of pains behind his knees and in his thighs. His mother noticed that his urine became dark brown during this time. He was admitted to hospital because of increasing pain in his legs and inability to walk. He had not been seriously ill in the past, and there was no family history of muscle disease. His parents were not consanguineous and both they and a sib were alive and well. On admission he was pale and unwell. Both thighs were considerably swollen and exquisitely tender on palpation. There was pain on handling his calves and also the muscles of the upper arms. Movements in all limbs were poor and he was unable to raise his legs; both feet were extended in plantar flexion (Fig. 2). Examination was otherwise normal.

Routine investigations were essentially normal but there was a neutrophil leucocytosis and the sedimentation rate was raised. The serum calcium was low at 4.0 $\mathrm{mEq} / \mathrm{l}$. Unfortunately phosphate was not measured and there were no further estimations of serum calcium. The urine was smoky and was chemi- 


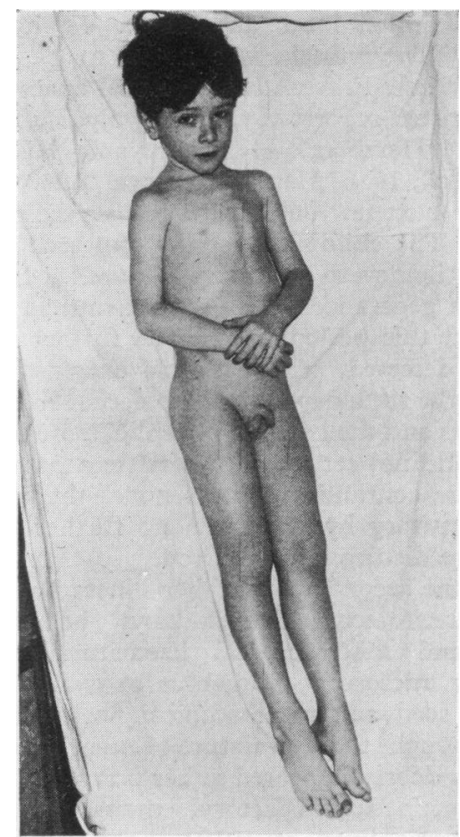

FIG. 2.-Case 3. Feet in plantar flexion, thighs swollen

cally positive for blood and albumin. On microscopy no cells were seen. Spectroscopy showed the pigment to be myoglobin. The serum aspartate aminotransferase was 1270 units; alanine aminotransferase 370 units; creatine phosphokinase over 6000 units; aldolase 95 units; EMG and conduction studies: 'nerve conductions are normal: needle EMG showed high frequency low voltage polyphasic units suggestive of a polymyositis' (Dr. J. A. R. Lenman). Muscle biopsy was taken from the left thigh two weeks after the onset of the child's illness.

The level of enzymes in the blood slowly returned to normal and the child made an uninterrupted recovery. He was discharged from hospital three weeks after the onset of the illness with no evidence of any residual atrophy or paralysis. He has remained well.

\section{Case 2.}

\section{Pathological Data}

Muscle biopsy. This was taken from the right quadriceps two days after admission. Histological findings were identical with those found in the muscle at necrospy and described below.

Necropsy. This was performed 7 hours after death. Significant pathological findings were confined to the skeletal muscles and the kidneys.

Muscles. All the muscles were pale. Portions of the quadriceps, intercostals, diaphragm, and sternomastoid were fixed in $10 \%$ buffered formalin for light microscopy and fresh frozen for enzyme histochemistry. Microscopically the fibres showed little variation in size throughout each section of muscle examined (i.e. 12-20 $\mu$, average $16 \mu$, normal for age). The most striking feature was a haphazard focal necrosis of muscle fibres (Fig. 3). A few fibres appeared swollen, with loss of cross striation and poor staining reaction (Fig. 4). Others were fragmented or in the process of phagocytosis. There was extensive necrosis in the diaphragm, intercostals, and quadriceps, but only focal lesions in the sternomastoid muscles. There was no replacement of muscle by fat or fibrous tissue and no sarcoplasmic basophilia or vesicular nuclei with prominent nucleoli to indicate regeneration. Staining with Azur $B$ for RNA was negative. Inflammatory infiltrate was limited to an occasional polymorph or lymphocyte. Muscle spindles, peripheral nerves, and blood vessels all appeared normal. Enzyme histochemistry showed no abnormality of acid phosphatase, phosphorylase, adenosintriphosphatase or lactic, malic, and succinic dehydrogenase.

Kidneys. Macroscopically both kidneys were enlarged and swollen. They weighed $80 \mathrm{~g}$ each, more than twice the normal weight for a child of 14 months. The subcapsular surface showed numerous petechial haemorrhages and the cortex was pale and increased in width while the medulla was intensely congested. Calyces and pelvis were filled with a reddish-brown granular material.

Microscopically there were the features of acute distal tubular necrosis. The glomeruli showed no abnormality. A few proximal convoluted tubules were dilated and some of them contained a little hyaline material. Distal tubules showed various stages of degeneration. There was dilatation of the lumen and flattening of the epithelium with cytosplasmic basophilia, prominent nuclei, and an occasional mitotic figure. The lumina of these tubules were filled with desquamated cells, polymorphs, and an occasional cast. Collecting tubules were full of granular and pigment casts.

The interstitial tissue showed an inflammatory infiltrate which was particularly prominent at the corticomedullary junction and consisted of neutrophil polymorphonuclear leucocytes, lymphocytes, and plasma cells. The arteries in all the sections examined appeared normal but many small veins were partially occluded by organizing thrombus. An occasional tubulo-venous anastomotic lesion was present (Fig. 5). Intravascular haemopoiesis was seen in the vasa recta of the medulla.

The most striking feature of the renal histology was the number and variety of the pigment casts occluding distal and collecting tubules and lying free in the pelvis. The casts were in a variety of shapes-balls, chains, crystals, and many were clearly laminated in appearance (Fig. 6). An attempt was made to define the exact composition of the casts by a variety of histological methods. These included the special methods for the demonstration of fibrin at all ages and also special combination stains suitable for the kidney (Lendrum et al., 1962; Lendrum, Fraser, and Slidders, 1964) together with the Amido black method for haemoglobin (Puchtler and Sweat, 1962). These confirmed that the casts contained old and recent deposits of fibrin, haemoglobin, myoglobin, and derivatives. 


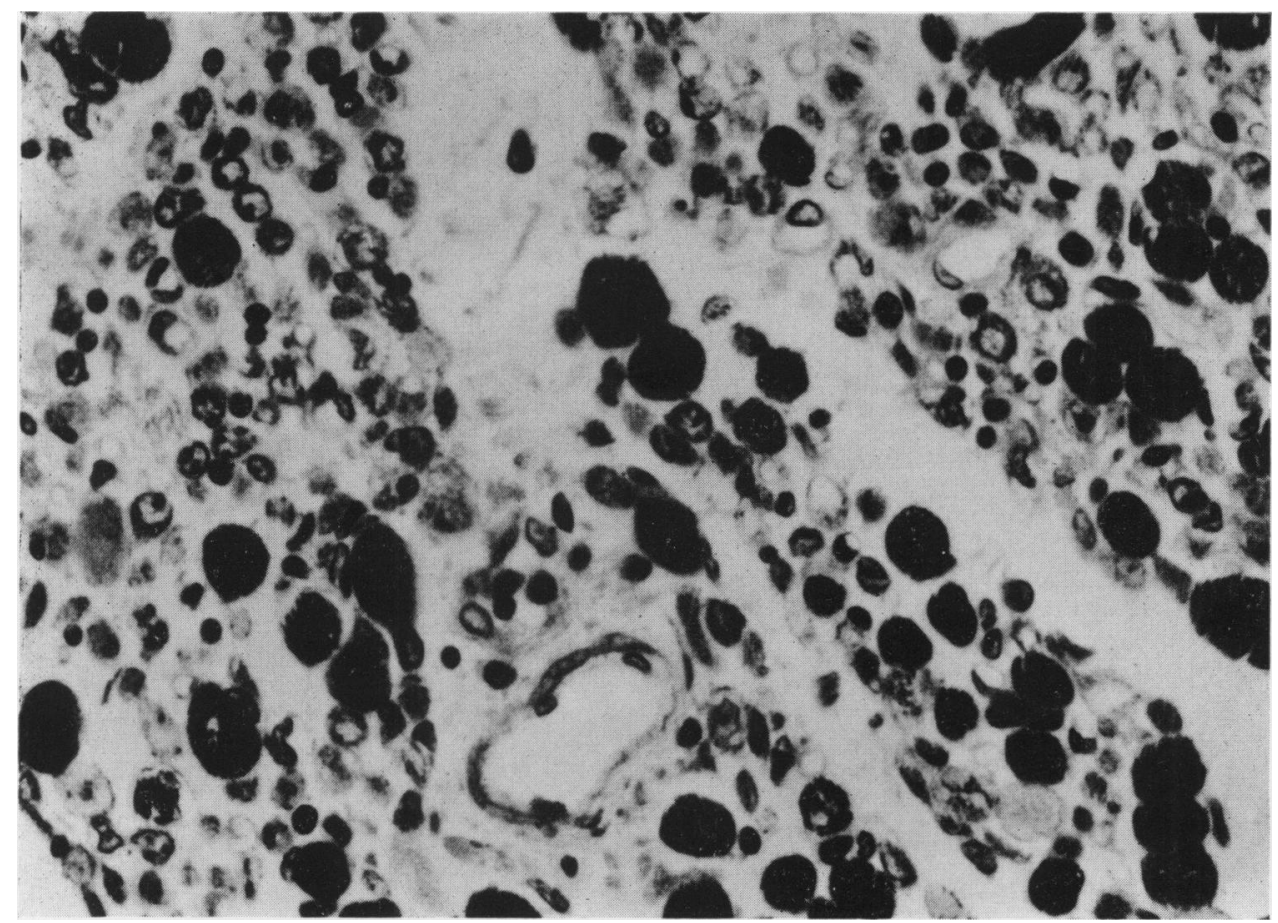

FIG. 3.-Case 2. Quadriceps showing stippled areas of focal necrosis. (Phosphotungstic acid haematoxylin. $\times$ 670.)

\section{Case 3.}

Muscle biopsy. A biopsy was taken from the right quadriceps 12 days after admission when the myoglobinuric episode had subsided and muscle pain was less severe. The biopsy was divided into four fragments which were fixed in formol corrosive for light microscopy, frozen by liquid hexane for enzyme histochemistry, fixed in glutaraldehyde for electronmicroscopy studies, and frozen at $-20^{\circ} \mathrm{C}$ for biochemistry.

Microscopically sections stained with $\mathrm{H}$. and $\mathrm{E}$. PAS, PTAH and picro-Mallory showed no significant abnormality. There was no evidence of muscle fibre regeneration and Azur B staining failed to demonstrate RNA. Enzyme histochemistry also showed no abnormality of acid phosphatase, phosphorylase, adenosintriphosphatase oxylactic, malic, and succinic dehydrogenase.

Electron microscopy. Small selected blocks of tissue were removed from the biopsy and fixed in ice-cold $5 \%$ glutaraldehyde in cacodylate buffer $0.1 \mathrm{M}$ for 4 hours with subsequent fixation in $1 \%$ osmium tetroxide for 1 hour. After alcohol dehydration araldite embedding was carried out. Sections were cut on an LKB Ultrotome, and stained with lead citrate. The muscle fibre myofibrils showed a variety of changes varying from Z-band irregularity or slight myofibrillar loss to almost complete loss of the constituent myofilaments. Adjacent myofibrils were often morphologically normal. In a few regions all muscle fibre architecture was lost, with fibrils fused together and only fragments of disorganized Z-bands remaining; interfibrillar structures including mitochondria were then absent. Below the sarcolemma and between the myofibrils of many regions there was an accumulation of amorphous material of irregular shape without a limiting membrane which was particularly concentrated in areas of myofibrillar loss. Occasional large subsarcolemmal collections of this material were present where there was local elevation of the sarcolemma (Fig. 7). Identification of this material has not been achieved and apparently it is morphologically similar to that reported by Scarpelli, Greider, and Frajola (1963) who described it as 'necrotic sarcoplasm' and commented upon the absence of myofibrils in such areas. This substance does not appear to be artefact but could be coagulated proteinaceous material. Hampers and Prager (1964) found round bodies which contained particles resembling glycogen. Mitochondria varied considerably in appearance with many showing little definite change but others were enlarged and excessively round with a considerable loss of internal cristae. The sarcolemma was remarkably well preserved and sarcoreticulum and T-tubules showed no change other than local loss of their normal relation to myofibrils where these structures were severely changed or lost. Nuclei were also normal morphologically. Small groups of RNA-like particles were occasionally found related to myofibril damage and may represent a regeneration response to injury. 


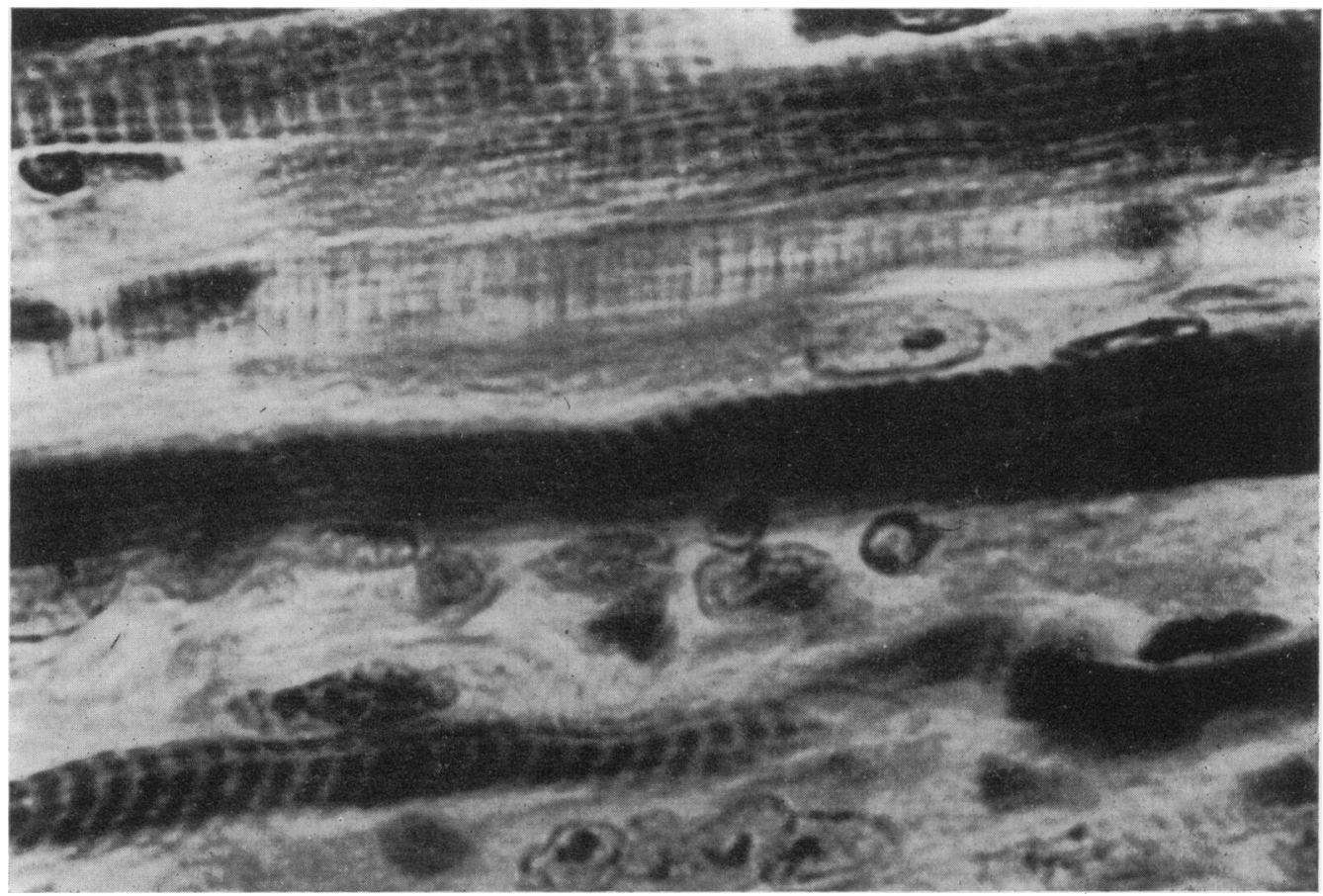

FIG. 4.-Case 2. Quadriceps showing swollen fibres in various stages of degeneration with loss of cross striations. (Phosphotungstic acid haematoxylin. $\times 1500$.)

\section{Discussion}

The main intracellular constituents of muscle are protein, glycogen, potassium, and phosphorus. The immediate result of rhabdomyolysis is liberation of these substances into the plasma, causing constitutional and biochemical abnormalities.

Myoglobin. Among the muscle proteins is the pigmented myoglobin which is present in the sarcoplasm of striated muscle fibres and gives the dark red brown colour to the urine in acute muscle necrosis. Myoglobin is an iron protein compound and in structure it is very similar to haemoglobin, being a combination of proto-porphyrin, iron, and a specific globulin. Haemoglobin has four $\mathrm{Fe}$ atoms per molecule and a molecular weight of 68,000 , as compared with myoglobin which has a molecular weight of 17,500 and contains only one $\mathrm{Fe}$ atom. The chief function of myoglobin is that of a very temporary oxygen storehouse. It is not absolutely essential to muscle function, since the cytochromes can assume its role in the presence of an adequate supply of oxygen. However, during brief periods of relative muscle anoxia, myoglobin reduces the need for glycolytic processes by releasing its con- tained oxygen and allowing a continuance of the much more efficient oxidative breakdown of lactate, pyruvate, and similar metabolites (Adams, DennyBrown, and Pearson, 1962).

Both myoglobin and haemoglobin impart a redbrown colour to the urine, and give positive results on standard testing for the presence of blood in urine. To distinguish these two pigments the simplest, but not the most reliable, method is the ammonium sulphate precipitation test, in which at $80 \%$ concentration of ammonium sulphate, haemoglobin precipitates while myoglobin does not (Blondheim, Margoliash, and Shafrir, 1958). Spectrophotometry is more specific, but since the absorption spectra of oxyhaemoglobin and oxymyoglobin are very similar, difficulties may arise. Electrophoresis or ultracentrifugation are perhaps the most specific methods available.

A normal coloured plasma in the presence of a urine which is benzidine-positive is suggestive of myoglobinuria. This is because the degree of binding, and therefore renal clearance of haemoglobin and myoglobin, is very different. Free extracorpuscular haemoglobin arises at a plasma concentration above $125 \mathrm{mg} / 100 \mathrm{ml}$, but unbound 

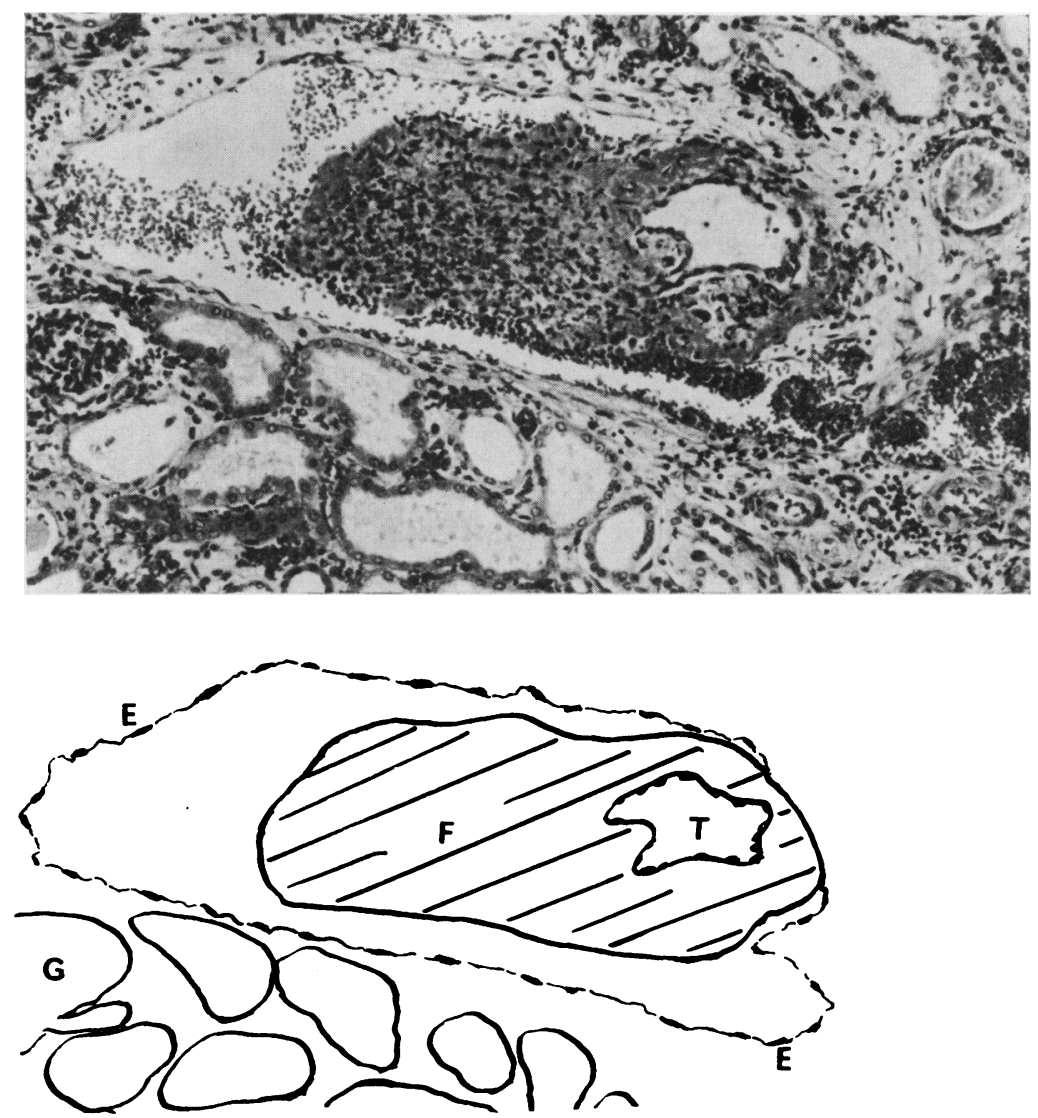

FIG. 5.-Case 2. Kidney: showing tubulo-venous anastomosis. The tubule is surrounded by organized thrombus and has herniated through the wall of a small vein. $E$, Endothelium of vein. $F$, Fibrin thrombus.

Haematoxylin and eosin. $\times 200$.)

$T$, Tubule with flattened epithelium. $G$, Glomerulus.

myoglobin at a concentration of only $25 \mathrm{mg} / 100 \mathrm{ml}$. In consequence, as neither pigment will colour the plasma at a concentration below $40 \mathrm{mg} / 100 \mathrm{ml}$, myoglobin appears in the urine before it is visible in the plasma.

Myoglobin, like haemoglobin, may cause distal renal tubular necrosis. As it is soluble at a basic $p \mathrm{H}$ it has been suggested that alkalinization of the urine may protect the kidney, but despite this precaution in some instances, as in Case 2, tubular necrosis has occurred. The fine needle-shaped crystals of myoglobin which were initially seen in Case 2 did not reappear once the urine had become alkaline: they were similar to those described and illustrated by Berenbaum, Birch, and Moreland (1955).

Glycogen. The main carbohydrate constituent of muscle is glycogen and other carbohydrate intermediaries in the glycolytic series are only present in small amounts. During rhabdomyolysis blood glycogen levels may be raised (Bowden et al., 1956) and glycosuria has often been noted (Buchanan and Steiner, 1951; Schaar, 1955; Favara et al., 1967). It was this, in association with the severe metabolic acidosis and ketosis, that led to the diagnosis of diabetic ketosis as the cause of death in Case 1; similarly in Case 2, glycosuria, ketonuria, and a metabolic acidosis were found though the blood glucose was within normal limits.

Potassium. Muscle contains a large amount of potassium, and its release during cell damage may give rise to cardiac arrhythmias: sudden or early deaths in acute muscle damage may have followed ventricular fibrillation. The rapidly fatal illness in Case 1 was similar to that reported in proven cases of idiopathic paroxysmal myoglobinuria (Bowden 


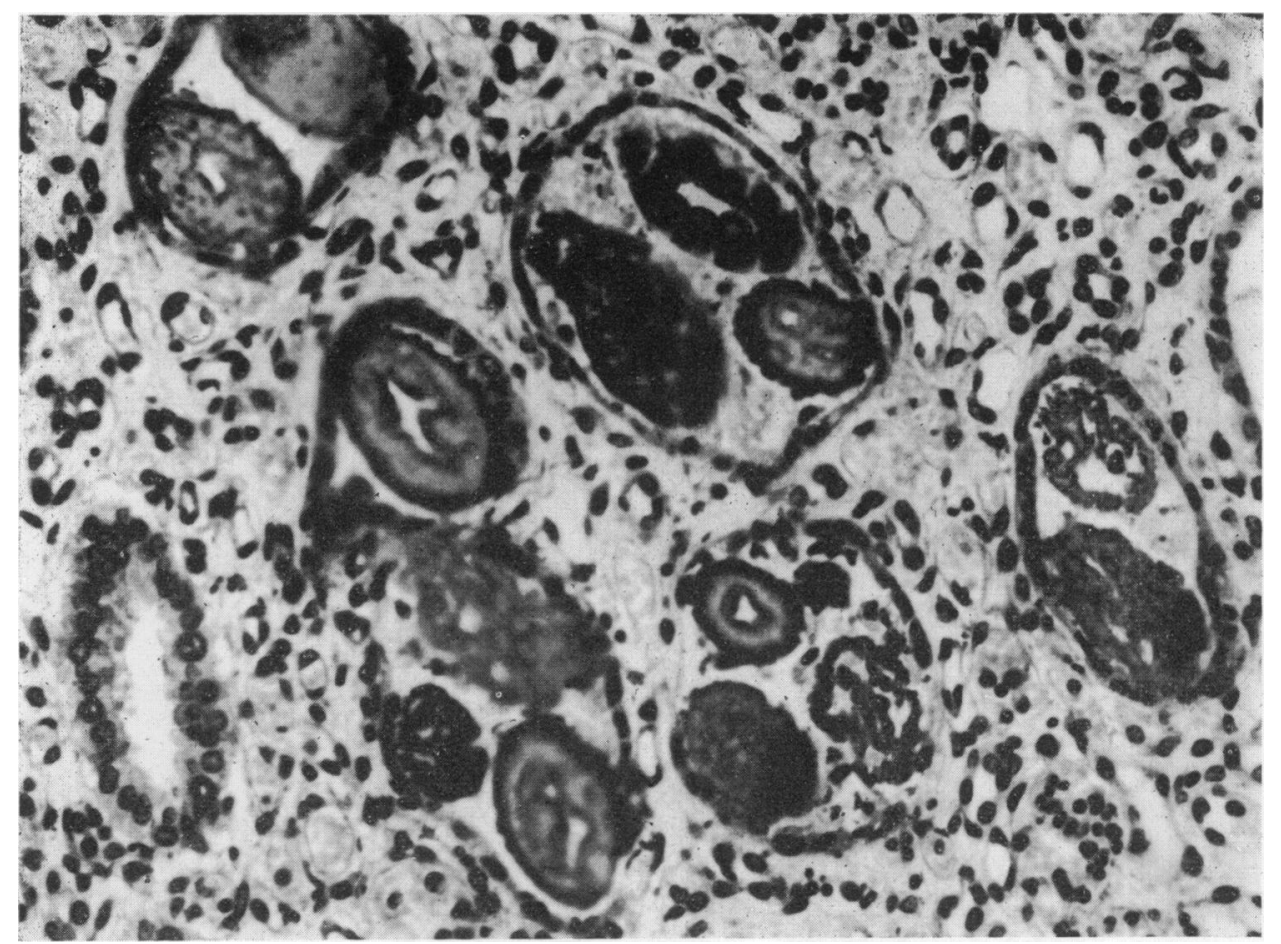

FIG. 6.-Kidney: casts in collecting tubules showing bizarre staining effects. (Obadiah method. $\times 280$.)

et al., 1956; Favara et al., 1967). In some instances a very high serum potassium has been recorded (Hed, 1955). In both Cases 1 and 2 the plasma potassium was high, and in Case 2 the ECG findings were consistent with hyperkalaemia.

Phosphorus. The large amount of intracellular phosphorus in muscle is present mainly as adenosine triphosphate and phosphocreatinine, and it is probable that during severe and acute rhabdomyolysis hyperphosphataemia occurs. In Case 2 the serum phosphate on the second and third day was raised, and the urinary phosphate/creatinine ratios were higher than the normal values published by Thalassinos et al. (1970). They reported a ratio ranging from 0.75 to 1.9 in children under 2 years of age whereas in our patient the ratios were $5 \cdot 0$ and $2 \cdot 3$. No calcium was present in the urine at this time. We believe that the initial hyperphosphataemia caused the hypocalcaemic tetany, and that as the raised serum phosphate fell during the first three days $\left(\mathrm{HPO}_{4} 4 \cdot 3,4 \cdot 0,2 \cdot 7 \mathrm{mEq} / 1\right.$; normal range $2 \cdot 1-3 \cdot 5 \mathrm{mEq} / \mathrm{l}$.) the child's serum calcium returned to normal levels $(2 \cdot 7,3 \cdot 4,4 \cdot 4$ $\mathrm{mEq} / 1$; normal range $4 \cdot 5-5 \cdot 7 \mathrm{mEq} / 1$.). If the product, ionized $\mathrm{Ca} \times \mathrm{PO}_{4}$ (as $\mathrm{mEq} / \mathrm{l}$.) exceeds 15 , deposition of calcium and phosphorous salts may result and it is of interest that in Reiner's first case (Reiner et al., 1956) and that recorded by Ford (1966) calcium phosphate was found in the necrotic muscle tissue. Tetany is a previously unrecognized complication of this illness, though in the patient described by Tavill et al. (1964) both hypocalcaemia and hyperphosphataemia were recorded during the first few days and thought to be the result of acute renal failure. Our observations are of particular interest since in over half the cases of idiopathic rhabdomyolysis the patients' feet have been noted to be in the equinus position, indeed many writers refer to the 'ballet dancer' position as a typical finding (see Fig. 2). While pedal spasm may partly be directly due to muscle injury, serum calcium and phosphorus estimations in future cases should clarify this point.

It is interesting that hyperphosphataemia and hypocalcaemia have recently been reported in a patient with malignant hyperpyrexia during general anaesthesia in whom the authors demonstrated considerable muscle damage (Denborough et al., 1970a). Though the aetiology of malignant hyperpyrexia is unknown, it is now recognized that it may occur in patients with an underlying abnor- 


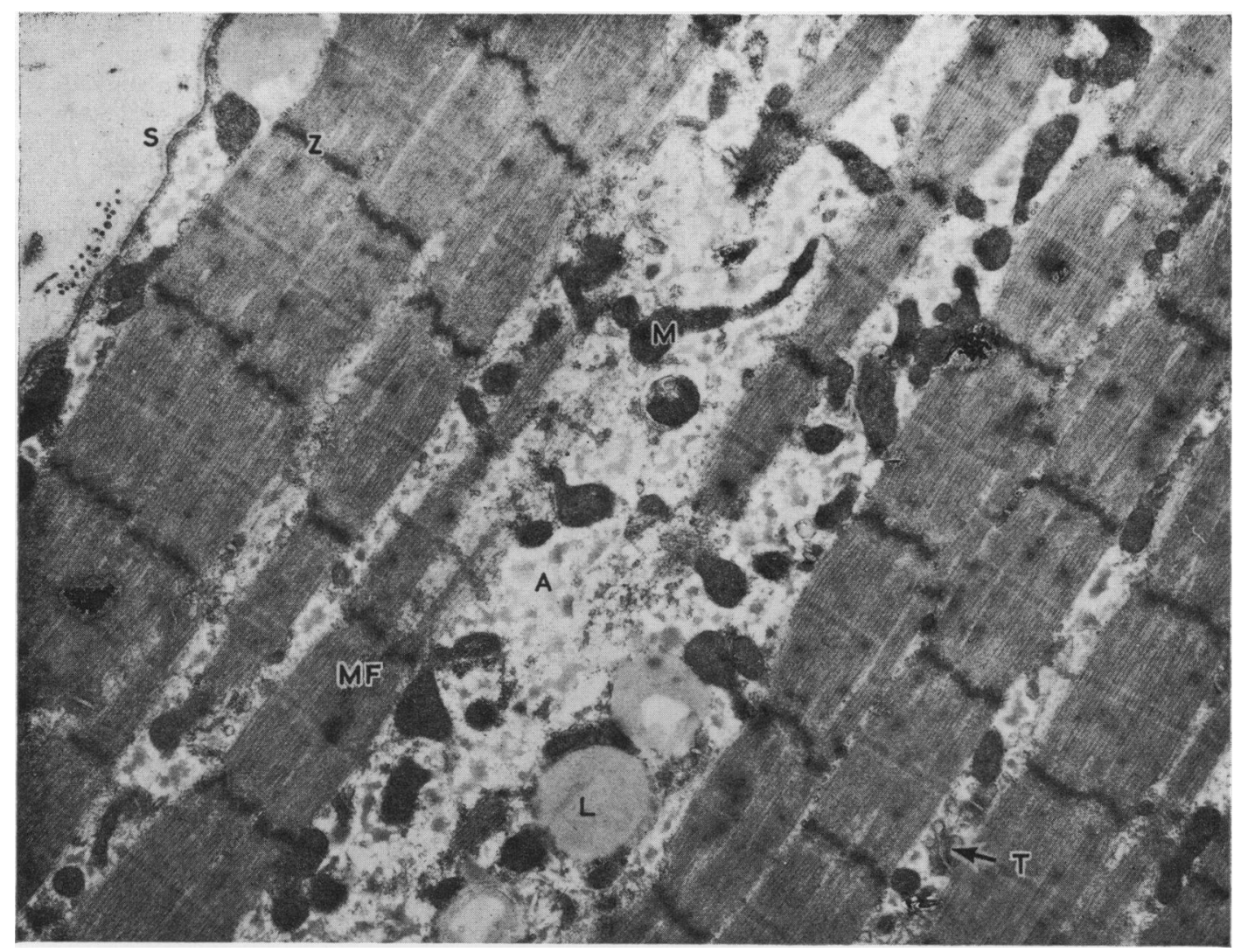

FIG.7.-Case 3. An area of myofibril and myofilament loss is present, which contains three round lipid bodies. Within the intermyofibrillar spaces and particularly in the region of myofibril destruction there is irregularly shaped amorphous material the nature of which is not known but which might be coagulated proteinaceous material. Mitochondria show no gross internal defects but they have lost their normal topographic relations. The sarcolemma and $T$-systems also show no defect. ( $\times 14,450$.) $A$ =amorphous material; $M=$ mitochondria; $S=$ sarcolemma; $Z=Z$ lines; $L=$ lipid; $M F=$ myofibril; and $T=T$ - system.

mality of skeletal muscle (Steers, Tallack, and Thompson, 1970; Denborough et al., 1970b) and it has been suggested that it is a severe rhabdomyolysis which leads to the hyperpyrexia (Denborough et al., 1970a). These facts are relevant because, though rhabdomyolysis has only recently been incriminated in malignant hyperpyrexia, myoglobinuria is recognized and muscular hypertonicity with carpopedal spasm reported (Purkis et al., 1967).

An added risk with hypocalcaemia is that its association with hyperkalaemia will aggravate cardiac arrhythmias which may prove fatal.

Abnormal urinary amino acid patterns have been found in patients with muscle necrosis (Bowden et al., 1956), the major abnormality being, as in Case 2, an increased excretion of taurine. $\beta$-amino- isobutyric acid was found in the urine of Case 2 over the first three days but not thereafter. Though this compound is normally found in $5-10 \%$ of the population, its disappearance from later urine specimens suggests that it arose during the extensive rhabdomyolysis. Increased amounts of $\beta$-aminoisobutyric acid has been noted in the urine of subjects with disorders associated with tissue destruction, and it is thought to arise from the breakdown of thymine, a constituent of DNA (Levey, Woods, and Abbott, 1963).

Apart from these biochemical abnormalities, the plasma level of muscle enzymes, particularly creatine phosphokinase, is raised. There is often an associated fever and leucocytosis. Rhabdomyolosis causes pain, oedema, and partial or complete paralysis of the muscles involved. In 
some recorded cases this latter finding has occasioned a diagnosis of poliomyelitis, and severe respiratory difficulties have caused death (Buchanan and Steiner, 1951).

Causes of rhabdomyolysis. Acute rhabdomyolysis has been reported in a number of different disorders. It may follow a crush injury, or the occlusion of a major limb artery with secondary ischaemic necrosis of skeletal muscle. During prolonged convulsions there may be relative tissue anoxia and high voltage accidents will cause direct tissue damage. Persons with polymyositis or a muscular dystrophy occasionally develop myoglobinuria and an alcoholic myopathy with myoglobinuria is recognized. In normal subjects rhabdomyolysis can follow severe exercise, and in military groups which emphasize physical fitness, the incidence of rhabdomyolysis is especially high (Smith, 1968). There have been three epidemics of Haff disease in which myoglobinuria seems to be of infective or toxic aetiology, the epidemics occurring in Eastern Europe lakeside communities, who have ingested fish and eels caught in inlets ('haff') thought to be contaminated by factory waste products (Berlin, 1948). Finally, there is a group of patients in whom the cause of the myoglobinuria is unknown, and it is to these that the term idiopathic recurrent rhabdomyolysis or paroxysmal myoglobinuria has been given.

Idiopathic rhabdomyolysis. The first recorded case of myoglobinuria is credited to Meyer-Betz (1910) who noted that a 13-year-old boy had recurrent episodes of black or bloody urine associated with severe muscle weakness. For this reason Meyer-Betz's name is often linked with idiopathic paroxysmal myoglobinuria, though it is probable that his patient in fact suffered from a form of muscular dystrophy. In 1959 Korein, Coddon, and Mowrey reviewed all those cases recorded as idiopathic paroxysmal myoglobinuria. They suggested that two main types could be differentiated. In the first, Type I, the disease appeared to be precipitated by exertion, and the second, Type II, was usually associated with or preceded by an infection. Korein suggested that Type I should be called exertional myoglobinuria and Type II toxic myoglobinuria. Later reviews have included those by Bowden et al. (1956), Wheby and Miller (1960), and Verger and Battin (1962). We have reviewed the literature, but included only those cases starting in childhood (15 years or younger). We have used the same clinical differentiation as Korein, but our findings differ slightly, presumably because of the age restriction we have used. Tables I and II detail these individual cases and Table III summarizes the main features.

In this paediatric series the average age on onset of toxic myoglobinuria (Type II) is earlier and the disease more common than exertional myoglobinuria (Type I), though in adults the latter is the more common illness. There is little difference between the sexes in the incidence of toxic myoglobinuria, but there is a predominance of males with exertional myoglobinuria. In the occasional patient myoglobinuria has followed either infection or

Idiopathic Rhabdomyolysis T⿸厃㔾pe

\begin{tabular}{|c|c|c|c|c|c|c|}
\hline Author & $\begin{array}{l}\text { Age } \\
(y r)\end{array}$ & Sex & $\begin{array}{c}\text { Age at } \\
\text { Onset }\end{array}$ & $\begin{array}{l}\text { Family } \\
\text { History }\end{array}$ & Exertion & Episंgdes \\
\hline Bywaters and Dible, 1943a & 24 & $\mathbf{M}$ & Early childhood & - & + & 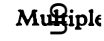 \\
\hline $\begin{array}{l}\text { Spaet et al., } 1954 \\
\text { Hed, } 1955 \\
\text { Reiner } \text { et al., } 1956 \text { (Case 1) } \\
\text { Segar, } 1959 \\
\text { Javid et al., } 1959 \\
\text { Lyons, } 1963 \\
\text { Tavill et al., } 1964 \\
\text { Rowland et al., } 1964 \text { (Case 2) } \\
\text { Rowland et al., } 1964 \text { (Case 5) } \\
\text { Boroian and Attwood, } 1965 \\
\text { Hinz et al., } 1965 \\
\text { Ford, } 1966\end{array}$ & $\begin{array}{r}23 \\
30 \\
46 \\
15 \\
18 \\
23 \\
28 \\
12 \\
16 \\
6 \\
17 \\
29\end{array}$ & $\begin{array}{l}\mathbf{M} \\
\mathbf{M} \\
\mathbf{M} \\
\mathbf{M} \\
\mathbf{M} \\
\mathbf{M} \\
\mathbf{F} \\
\mathbf{F} \\
\mathbf{M} \\
\mathbf{M} \\
\mathbf{M}\end{array}$ & $\begin{array}{c}\text { Early childhood } \\
14 \\
\text { Early childhood } \\
\text { Early childhood } \\
14 \\
\text { Early childhood } \\
5 \\
12 \\
14 \\
6 \\
15 \\
\text { Early childhood }\end{array}$ & $\begin{array}{l}\overline{+} \\
\overline{-} \\
\overline{+} \\
\overline{-} \\
\overline{+}\end{array}$ & $\begin{array}{l}+ \\
+ \\
+ \\
+ \\
+ \\
+ \\
+ \\
+ \\
+ \\
+ \\
+ \\
+\end{array}$ & 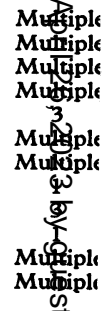 \\
\hline $\begin{array}{l}\text { Ozsoylo and Akgün, } 1966 \\
\text { Goldberg and Chakrabarti, } 1966 \\
\text { Engel } \text { et al., } 1970 \\
\text { Engel } \text { et al., } 1970\end{array}$ & $\begin{array}{l}21 \\
28 \\
18 \\
18\end{array}$ & $\begin{array}{l}\mathbf{M} \\
\mathbf{M} \\
\mathbf{F} \\
\mathbf{F}\end{array}$ & $\begin{array}{l}9 \\
7 \\
5 \\
5\end{array}$ & $\begin{array}{l}- \\
+ \\
+\end{array}$ & $\begin{array}{l}+ \\
+ \\
+ \\
+\end{array}$ & $\begin{array}{l}\text { Mulpiplı } \\
\text { Multiplı } \\
\text { Mưpiplı } \\
\text { Mưpiplı }\end{array}$ \\
\hline
\end{tabular}


exertion and has even been apparently spontaneous. Recurrent attacks of myoglobinuria are more frequent in Type I, most cases of Type II having only one and usually less then three reported episodes. Fever and leucocytosis, which occur more regularly in Type II, probably reflect that this is the more acute illness. Korein noted uraemia less commonly in exertional myoglobinuria, though we have found it in this paediatric review with equal frequency in both types, suggesting that when exertional myoglobinuria starts in childhood it carries a more serious prognosis. Fatalities are more common in Type II. It is perhaps significant that no deaths have occurred in exertional myoglobinuria during childhood, but that the two fatalities which arose later resulted when the illness was apparently provoked or aggravated by an associated infection (Bywaters and Dible, 1943a; Ford, 1966). Residual muscle atrophy is rarely reported.

Histopathology. The two constant histological findings in the skeletal muscle in this condition are focal necrosis of fibres, and an absence of significant inflammatory infiltrate. Some authors (Haase and Engel, 1960; Reiner et al., 1956; Larsson et al., 1964; and Kossmann, Camp, and Engle, 1963) describe evidence of regeneration such as sarcoplasmic basophilia, proliferation of sarcolemmal nuclei, and the presence of multinucleate giant cells, but there was no suggestion of this in our Case 2 and there was no RNA activity on Azur B staining. Benoit, Theil, and Watten (1964), Hinz, Drucker, and Larner (1965), and Tavill et al. (1964) describe little change in the muscle in their reports, and the light microscopical appearance of the muscle biopsy of our Case 3 was essentially normal. Cardiac and smooth muscle are unaffected.

Acute tubular necrosis with renal failure is a wellrecognized complication of paroxysmal myoglobinuria and in a few of the described cases it has proved fatal. It appears to be an uncommon cause of death in the paediatric age group, and in fact our Case 2 appears to be the only reported child in which myoglobinuric nephropathy led to death. The histological picture in the kidneys was very similar to that described by Bywaters and Dible (1943b) in their review of traumatic anuria. There were severe lesions affecting the distal tubule with striking formation of pigment casts in the collecting tubules and occasional tubulo-venous anastomoses. This latter feature is rarely described in contemporary literature (Heptinstall, 1966), though emphasized as an important finding in acute tubular necrosis in the older reports (Dunn, Gillespie, and Niven, 1941).

Aetiology. The aetiology of paroxysmal myoglobinuria is unknown, but it may be that a metabolic defect exists, which under the stress of fever, infection, or exercise produces cell damage.

Abnormalities of muscle protein have been suggested and fetal myoglobin has been reported in some cases. Benoit et al. (1964) recorded such a case and Perkoff (1964) found increased concentration of fetal protein in the muscle of a patient with myoglobinuria. However, more recently on reexamination of his preparations, Perkoff has confirmed the observation of others (Wolfson et al.,

Reported Cases Starting in Childhood)

\begin{tabular}{|c|c|c|c|c|c|c|c|}
\hline $\begin{array}{c}\text { Febrile } \\
\text { Onset }\end{array}$ & $\begin{array}{l}\text { Associated } \\
\text { Illness }\end{array}$ & Uraemia & $\begin{array}{l}\text { Respiratory } \\
\text { Difficulty }\end{array}$ & Atrophy & Fatality & Myoglobinuria & $\begin{array}{c}\text { Muscle } \\
\text { Degeneration } \\
\text { Confirmed } \\
\text { Histologically }\end{array}$ \\
\hline Not usually & $\begin{array}{l}\text { Respiratory infection } \\
\text { in fatal illness }\end{array}$ & + & & 一 & + & $\mathbf{H b}$ & + \\
\hline 一 & 一 & + & - & 一 & 一 & + & 一 \\
\hline - & - & 一 & 一 & - & 一 & + & 一 \\
\hline Not usually & $\bar{Z}$ & $\begin{array}{l}+ \\
+\end{array}$ & $\overline{+}$ & & - & $\begin{array}{c}\mathbf{H b} \\
+\end{array}$ & $\stackrel{+}{-}$ \\
\hline- & - & 一 & 一 & 一 & 一 & + & - \\
\hline 一 & 一 & - & 一 & 一 & 一 & + & 一 \\
\hline 一 & - & + & 一 & 一 & 一 & + & + \\
\hline+ & Diarrhoea & - & 一 & 一 & 一 & + & 一 \\
\hline - & 二 & \pm & - & - & E & $\begin{array}{c}\mathrm{Hb} \\
+\end{array}$ & - \\
\hline - & - & - & 一 & 一 & - & $\begin{array}{l}+ \\
+\end{array}$ & - \\
\hline+ & $\begin{array}{l}\text { Coryza/diarrhoea in } \\
\text { fatal illness }\end{array}$ & + & + & - & + & + & + \\
\hline- & - & - & - & - & - & + & 一 \\
\hline 一 & Diarrhoea & + & 一 & - & 一 & + & 一 \\
\hline - & = & - & - & E & - & $\stackrel{+}{-}$ & Z \\
\hline & & & & & & & \\
\hline
\end{tabular}


Idiopathic Rhabdomyolysis Ty 1

\begin{tabular}{|c|c|c|c|}
\hline Author & & $\begin{array}{l}\text { Age } \\
(\mathrm{yr})\end{array}$ & Sex \\
\hline $\begin{array}{l}\text { Debré et al., } 1934 \\
\text { Huber et al., 1938 } \\
\text { Buchanan and Steiner, } 1951 \\
\text { Stokes, 1953 } \\
\text { Schaar, 1955 } \\
\text { Berenbaum et al., } 1955 \\
\text { Bowden et al., } 1956 \\
\text { Bowden et al., 1956 } \\
\text { Bowden et al., 1956 } \\
\text { Bowden et al., 1956 } \\
\text { Watson and Ainbender, } 1959 \\
\text { Wheby and Miller, 1960 } \\
\text { Wheby and Miller, 1960 } \\
\text { Haase and Engel, } 1960 \\
\text { Bailie, 1964 }\end{array}$ & 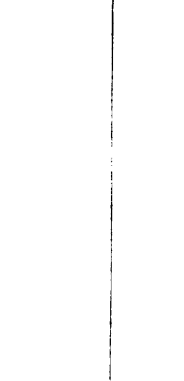 & $\begin{array}{r}6 \\
4 \\
4 \\
15 \\
0 \\
10 \\
4 \\
8 \\
6 \frac{1}{2} \\
4 \\
6 \\
16 \\
15 \\
7 \\
3\end{array}$ & $\begin{array}{l}\text { F } \\
M \\
M \\
\text { F } \\
\text { M } \\
\text { F } \\
\text { M } \\
\text { F } \\
\text { M } \\
\text { F } \\
\text { M } \\
\text { F } \\
\text { F } \\
\text { M } \\
\text { M }\end{array}$ \\
\hline $\begin{array}{l}\text { Bacon, } 1967 \\
\text { Miller and Gross, } 1967 \\
\text { Favara et al., } 1967 \\
\text { Favara et al., } 1967 \\
\text { Favara et al., } 1967 \\
\text { Current report Case } 1 \\
\text { Case } 2 \\
\text { Case } 3\end{array}$ & & $\begin{array}{l}14 \\
11 \\
2 \frac{1}{2} \\
9 \\
9 / 12 \\
3 \\
18 / 12 \\
7\end{array}$ & $\begin{array}{l}\mathbf{M} \\
\mathbf{M} \\
\mathbf{M} \\
\mathbf{M} \\
\mathbf{M} \\
\mathrm{F} \\
\mathrm{F} \\
\mathbf{M}\end{array}$ \\
\hline \multicolumn{4}{|c|}{$\begin{array}{l}\text { Hb, myohaemoglobinuria. `Possible association. ?Unknown. } \\
\text { TABLE III } \\
\text { diopathic Rhabdomyolysis (Starting in Childhood) }\end{array}$} \\
\hline & $\begin{array}{c}\text { Type I } \\
\text { (Exertional) }\end{array}$ & \multicolumn{2}{|c|}{$\begin{array}{c}\text { Type II } \\
\text { (Non-exertional) }\end{array}$} \\
\hline $\begin{array}{l}\text { Cases } \\
\text { Average age onset (yr) } \\
\text { Positive family history } \\
\text { Associated exertion } \\
\text { Associated illness } \\
\text { Multiple episodes } \\
\text { Fever } \\
\text { Uraemia and/or dyspnoea } \\
\text { Fatal } \\
\text { Muscular atrophy }\end{array}$ & $\begin{array}{c}17 \\
(\mathrm{M} 13, \mathrm{~F} 4) \\
10 \\
3 \\
17 \\
4 \\
13 \\
5 \\
8 \\
2 \\
1\end{array}$ & \multicolumn{2}{|c|}{$\begin{array}{c}23 \\
\text { (M 14, F 9) } \\
5 \\
4 \\
2 \\
20 \\
6 \\
20 \\
10 \\
8 \\
3\end{array}$} \\
\hline
\end{tabular}

1967) that the major haemoprotein was fetal haemoglobin and he believes that reports of fetal myoglobin in patients with myoglobinuria must be considered to have alternative explanations (Perkoff, 1968). There have been no other reports of abnormal myoglobins in idiopathic rhabdomyolysis, but since inherited structural variation of human myoglobin does occur it may be that in some instances such an abnormality is responsible for paroxysmal myoglobinuria (Boyer, Fainer, and Naughton, 1963).

It has often been suggested that rhabdomyolysis might be precipitated by an intracellular disorder of carbohydrate metabolism. Hed (1955) found that in three brothers with myoglobinuria, paroxysms were always precipitated by exercise,

and that fasting greatly facilitated the ease with which attacks could be induced. He was able to produce myoglobinuria in one brother while at rest by administration of a diet low in carbohydrate. Similarly, in the adult reported by Kontos et al. (1963) attacks of exertional myoglobinuria were aggravated by fasting, and exercise was better tolerated if preceded by a high caloric diet. The patient described by Ford (1966) noted that a large lunch on a hunting trip would avert the attack that would otherwise occur. Similar findings have been noted by other authors: Hinz et al. (1965) found raised blood lactic acid after exercise, and suggested the possibility that in some cases abnormalities may exist in the Krebs cycle. The family described by Favara et al. (1967) was considered to have an inborn error of glycogen metabolism with excessive phosphorylase activity. A curious disease with myoglobinuria is well recognized in veterinary medicine. Draught horses, after a weekend in stable on high caloric feeds and within an hour of starting heavy work, may fall to the ground with profound weakness and apparent pain in the limbs. The urine is dark and contains myoglobin. The condition is frequently fatal and it has been suggested that it results from excessive intracellular lactic acid production during glycolysis (Kreutzer, Strait, and Kerr, 1948).

In a comprehensive report, Larsson et al. (1964) have described 14 patients belonging to five families,
ర 


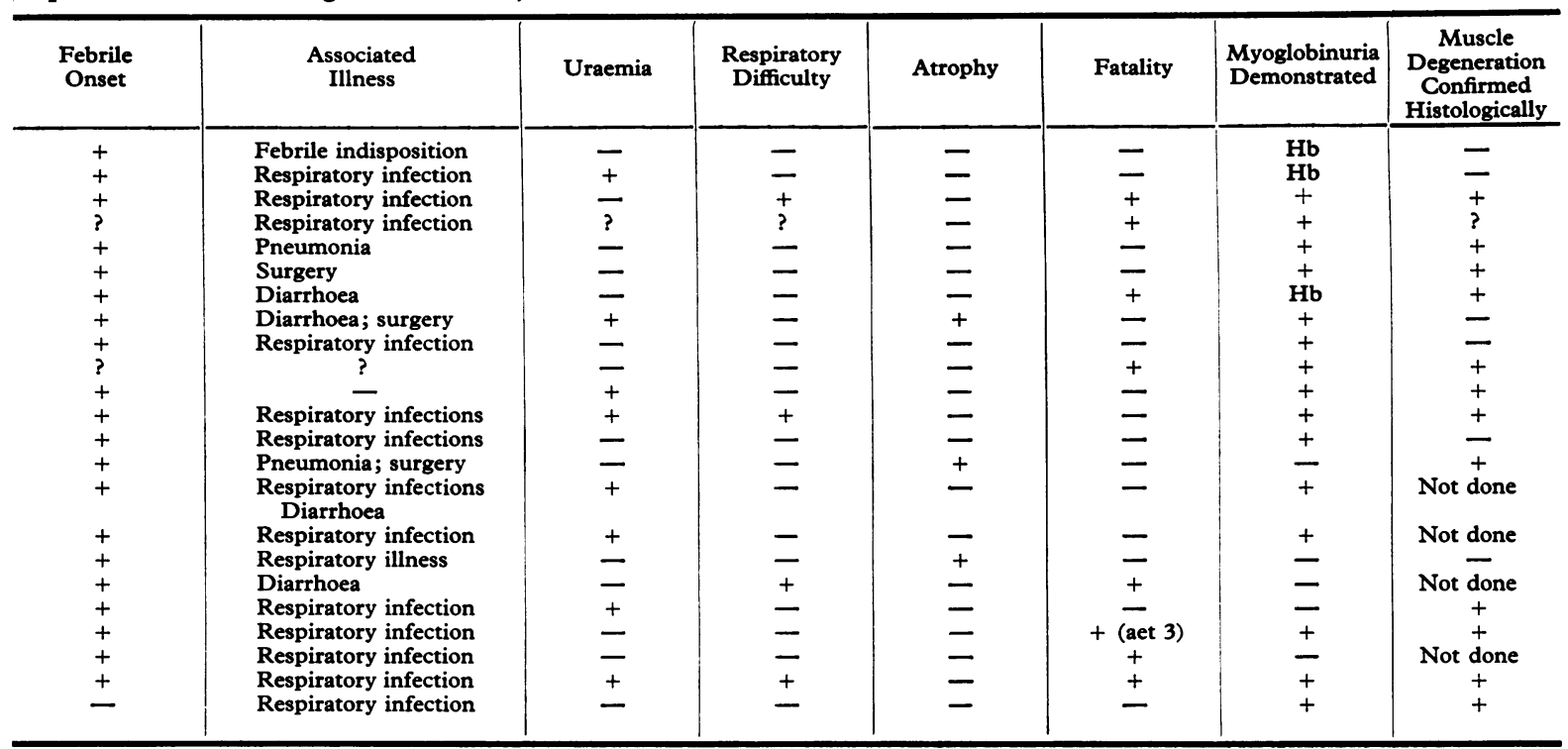

all of whom had a myopathy comparable in some respects to Type I myoglobinuria. Larsson showed that during exercise oxygen utilization in the patients' muscles was low, whereas lactic and pyruvic concentrations in the blood increased to a greater extent than in normal subjects, and he concluded that glycolysis was abnormal. As nearly all these patients had hypertrophy of the calf muscles, we have however not included them as examples of idiopathic myoglobinuria.

Recently, Engel et al. (1970) have described an apparent defect in the breakdown of long-chain fatty acids in identical twins with myoglobinuria. Since Fritz (1961) has shown that the energy supply of skeletal muscle, especially under sustained work performance, probably comes from plasma free fatty acids, it is surprising that abnormalities in fatty acid metabolism have not been more frequently reported. It is of interest that heart muscle in patients with myoglobinuria is normally unaffected, for cardiac muscle appears to depend largely on fatty acid for its energy supply (Lancet, 1970).

A number of patients with rhabdomyolysis have had diarrhoea and on stool culture a dysentery organism has been found (Bowden et al., 1956; Rowland et al., 1964); while this may be a chance finding, it is known that muscle degeneration can occur in typhoid fever. It is possible that the muscle changes in these cases were the result of an intestinal infection in children susceptible to muscle damage. Fever has been incriminated, Berg and Frenkel (1958) inducing myoglobinuria in their patient by raising his temperature with typhoid vaccine.

Acheson and McAlpine (1953) suggested that abnormal adrenal metabolism might be involved, and in their patient reported increased 17-oxosteroid excretion in the urine. In our Case 2, 24-hour urinary 17-oxosteroids on admission and during the subsequent day were 0.65 and $1.1 \mathrm{mg} / 24 \mathrm{hr}$, normal results in a child of this age. The 17hydroxycorticosteroids were raised to $10.4 \mathrm{mg} /$ $24 \mathrm{hr}$ during the first few days, falling to $5.5 \mathrm{mg} /$ $24 \mathrm{hr}$ subsequently. The initial high figures are the result of stress. In Case 3 the 17-oxosteroids were 0.9 and $1.6 \mathrm{mg} / 24 \mathrm{hr}$ on two occasions and the 17-hydroxycorticosteroids 3.4 and $3.6 \mathrm{mg} /$ $24 \mathrm{hr}$. All these results are within the normal range for a child of this age.

In some instances general anaesthesia has precipitated myoglobinuria though what part it plays in the exacerbation of rhabdomyolysis is unknown. It may be that the period of fasting, the relative anoxia, variations in temperature, or indeed the action of anaesthetic drugs including muscle relaxants themselves are of consequence. Recently it has been suggested that the frequently fatal malignant hyperpyrexia which has occurred during general anaesthesia follows rhabdomyolysis in 
susceptible individuals (Denborough et al., 1970a).

It will have become apparent how little is known about the aetiology of idiopathic recurrent rhabdomyolysis. It is probable that the reported cases represent a variety of different entities. In future cases, histochemistry and electron microscopy of muscle tissue with myoglobin finger printing, and investigation of carbohydrate and lipid metabolism, will be essential if abnormalities of these systems are to be determined.

Genetic transmission. There have been a few cases of paroxysmal myoglobinuria occurring in families. In those recorded by Bowden et al. (1956), Wheby and Miller (1960), Favara et al. (1967), and our own first 2 cases, sibs have been affected. In all these the disease has been of the so-called toxic type, and the illness has been severe, 6 of the 9 children having died, and in 2 who survived, sisters reported by Wheby and Miller (1960), recurrent severe episodes were recorded. Similarly in the family described by Fitz (1957) of 3 adult sibs with Type II myoglobinuria, 2 died during episodes of rhabdomyolysis. 3 brothers were reported by Hed (1955) with Type I myoglobinuria, but in only 1 did the illness start in childhood and in none was it fatal. The twins of Engel et al. (1970) survived recurrent episodes of exertional myoglobinuria.

It does seem that the prognosis, especially with Type II myoglobinuria, is more serious when there is a positive family history, though any patient with rhabdomyolysis must be regarded as having a potentially lethal disease. In a number of instances addenda have been added to published articles noting the later death of the recorded patient or a sib previously unknown to have the condition, and it may well be that the mortality is higher than the literature suggests. It is unfortunate that there is as yet no way in which the condition may be predicted before rhabdomyolysis occurs.

A recessive gene may be involved in these cases, though the proportion of children affected in many families suggests a dominant of incomplete penetrance. Ford's (1966) family, in which 2 brothers and their father were similarly affected, presumes a dominant inheritance. Many reports, however, have an inadequate family history or none at all, and the presence or absence of consanguinity of parents is seldom mentioned, though this was noted in the case of Tavill's patient. For this reason and because there are so few recorded cases it is impossible to do more than surmise at the genetic transmission involved.
Therapy. Treatment is unsatisfactory. Patients with exertional myoglobinuria should be advised to avoid excessive exercise and to take extra calories before undertaking any activity. During an episode of myoglobinuria the urine should be made alkaline and the urinary output maintained. Renal dialysis and respirator care may be necessary. In the presence of extensive muscle necrosis prophylactic antibiotics should be given. There is no evidence that steroids are of value in prophylaxis or therapy.

We thank Professor J. L. Henderson for his interest, Drs. Mary Kerr, Constance C. Forsyth, and S. G. F. Wilson for permission to report cases, Professor J. N. Walton, Newcastle General Hospital, for the use of his electron microscope laboratory, Mr. John Fulthorpe, Mr. Michael Taylor and Miss Margaret Jenkinson for technical assistance, and Mr. Ron Fawkes for photography.

\section{REFERENCES}

Acheson, D., and McAlpine, D. (1953). Muscular dystrophy associated with paroxysmal myoglobinuria and excessive excretion of ketosteroids. Lancet, 2, 372.

Adams, R. D., Denny-Brown, D., and Pearson, C. M. (1962). Diseases of Muscle. Kimpton, London.

Bacon, A. E., Jr. (1967). Acute idiopathic rhabdomyolysis with myoglobinuria. Delaware Medical fournal, 39, 302.

Bailie, M. D. (1964). Primary paroxysmal myoglobinuria. New England fournal of Medicine, 271, 186.

Benoit, F. L., Theil, G. B., and Watten, R. H. (1964). Myoglnbinuria and persistence of fetal myoglobin. Annals of Internal Medicine, 61, 1133.

Berenbaum, M. C., Birch, C. A., and Moreland, J. D. (1955). Paroxysmal myoglobinuria. Lancet, 1, 892.

Berg, P., and Frenkel, E. P. (1958). Myoglobinuria after spontaneous and induced fever. Annals of Internal Medicine, 48, 380.

Berlin, R. (1948). Haff disease in Sweden. Acta Medica Scandinavica, 129, 560 .

Blondheim, S. H., Margoliash, E., and Shafrir, E. (1958). A simple test for myohemoglobinuria. Fournal of the American Medical Association, 167, 453.

Boroian, T. V., and Attwood, C. R. (1965). Myoglobinuria. Fournal of Pediatrics, 67, 69.

Bowden, D. H., Fraser, D., Jackson, S. H., and Walker, N. F. (1956). Acute recurrent rhabdomyolysis (paroxysmal myohaemoglobinuria). Medicine, 35, 335.

Boyer, S. H., Fainer, D. C., and Naughton, M. A. (1963). Myoglobin; inherited structural variation in man. Science, 140, 1228.

Buchanan, D., and Steiner, P. E. (1951). Myoglobinuria with paralysis (Meyer-Betz disease). Archives of Neurology and Psychiatry, 66, 107.

Bywaters, E. G. L., and Dible, J. H. (1943a). Acute paralytic myohaemoglobinuria in man. Fournal of Pathology and Bacteriology, 55, 7.

Bywaters, E. G. L., and Dible, J. H. (1943b). The renal lesion in traumatic anuria. Fournal of Pathology and Bacteriology, 54,111

Debré, R., Gernez, C., and Sée, G. (1934). Crises myopathiques paroxystiques avec hémoglobinurie. Bulletins et Mémoires de la Société Médicale des Hópitaux de Paris, 50, 1640).

Denborough, M. A., Ebeling, P., King, J. O., and Zapf, P. (1970a). Myopathy and malignant hyperpyrexia. Lancet, $1,1138$.

Denborough, M. A., Forster, J. F. A., Hudson, M. C., Carter, N. G., and Zapf, P. (1970b). Biochemical changes in malignant hyperpyrexia. Lancet, 1, 1137.

Dunn, J. S., Gillespie, M., and Niven, J. S. F. (1941). Renal lesions in two cases of crush syndrome. Lancet, $2,549$. 
Engel, W. K., Vick, N. A., Flueck, C. J., and Levy, R. I. (1970). A skeletal muscle disorder associated with intermittent symptoms and a possible defect of lipid metabolism. New England fournal of Medicine, 282, 698.

Favara, B. E., Vawter, G. F., Wagner, R., Kevy, S., and Porter, E. G. (1967). Familial paroxysmal rhabdomyolysis in children. American Fournal of Medicine, 42, 196.

Fitz, T. E. (1957). Familial paroxysmal paralytic myoglobinuria West Virginia Medical fournal, 53, 264.

Ford, F. R. (1966). Diseases of the Nervous System in Infancy, Childhood and Adolescence, 5th ed. Thomas, Springfield, Illinois.

Fritz, I. B. (1961). Factors influencing the rates of long-chain fatty acid oxidation and synthesis in mammalian systems. Physiological Revierws, 41, 52.

Goldberg, W. H., and Chakrabarti, S. B. (1966). Idiopathic paroxysmal myoglobinuria with transient renal failure. Canadian Medical Association Fournal, 84, 681.

Haase, G. R., and Engel, A. G. (1960). Paroxysmal recurrent rhabdomyolysis. Archives of Neurology, 2, 410.

Hampers, C. L., and Prager, D. (1964). Myoglobinuric myopathy. Annals of Internal Medicine, 60, 476.

Hed, R. (1955). Myoglobinuria in man. Acta Medica Scandinavica, Suppl. 303.

Heptinstall, R. H. (1966). Acute renal failure. In Pathology of the Kidney, p. 652. Churchill, London.

Herzberg, S. B., Michener, W. M., and Kiser, W. S. (1967). Onset of paroxysmal myoglobinuria after tonsillectomy and adennidectomy. Cleveland Clinic Quarterly, 34, 159.

Hinz, C. F., Jr., Drucker, W. R., and Larner, J. (1965). Idiopathic myoglobinuria. American fournal of Medicine, 39, 49.

Huber, J., Florand, J., Lièvre, J. A., and Néret, Mme. (1938). Crises myopathique paroxystiques avec hémoglobinurie. Bulletins et Mémoires de la Société Médicale des Hópitaux de Paris, $\mathbf{5 4}, 725$.

Javid, J., Horowitz, H. I., Sanders, A. R., and Spaet, T. H. (1959). Idiopathic paroxysmal myoglobinuria. Archives of Internal Medicine, 104, 628 .

Kontos, H. A., Harley, E. L., Wasserman, A. J., Kelly, J. J., III, and Magee, J. H. (1963). Exertional idiopathic paroxysmal myoglobinuria: evidence for a defect in skeletal muscle metabolism. American fournal of Medicine, 35, 283.

Korein, J., Coddon, D. R., and Mowrey, F. H. (1959). The clinical syndrome of paroxysmal paralytic myoglobinuria. Neurology, 9. 767.

Kossmann, R. J., Camp, W. A., and Engle, R. L., Jr. (1963). Idiopathic recurrent rhabdomyolysis with myoglobinuria. American fournal of Medicine, 34, 554.

Kreutzer, F. L., Strait, L., and Kerr, W. J. (1948). Spontaneous myohaemoglobinuria in man. Archives of Internal Medicine, 81, 249.

Lancet (1970). Leading article. Muscle symptoms and fat oxidation, 1, 1096.

Larsson, L. E., Linderholm, H., Müller, R., Ringqvist, T., and Sörnăs, R. (1964). Hereditary metabolic myopathy with paroxysmal myoglobinuria due to abnormal glycolysis. Fournal of Neurology, Neurosurgery and Psychiatry, 27, 361.

Lendrum, A. C., Fraser, D. S., and Slidders, W. (1964). Further observations on the age changes in extravascular fibrin. Nederlandsch Tijdschrift voor Geneeskunde, 108, 2373.

Lendrum, A. C., Fraser, D. S., Slidders, W., and Henderson, R. (1962). Studies on the character and staining of fibrin. fournal of Clinical Pathology, 15, 401.

Levey, S., Woods, T., and Abbott, W. E. (1963). Urinary excretion of $\beta$-aminoisobutyric acid following surgical procedures. Metabolism: Clinical and Experimental, 12, 148.

Lyons, R. H. (1963). Myoglobinuria. New York State fournal of Medicine, 63, 2512.

Meyer-Betz, F. (1910). Beobachtungen an einem eigenartigen mit Muskellăhmungen verbundenen Fall von Hämoglobinurie. Deutsches Archiv für klinische Medizin, 101, 85.

Miller, B. H., and Gross, J. S. (1967). Acute rhabdomyolysis with myoglobinuria. Virginia Medical Monthly, 94, 213.

Ozsoylu, S., and Akgün, S. (1966). Idiopathic paroxysmal myoglobinuria. Turkish fournal of Pediatrics, 8, 99.

Perkoff, G. T. 1964). Studies of human myoglobin in several diseases of muscle. New England Fournal of Medicine, 270, 263.

Perkoff, G. T. (1968). Further consideration of fetal muscle hemeprotein. Fournal of Laboratory and Clinical Medicine, 71, 610.

Puchtler, H., and Sweat, F. (1962). Amidoblack as a stain for hemoglobin. Archives of Pathology, 73, 245.

Purkis, I. E., Horrelt, O., de Young, C. G., Fleming, R. A. P., and Langley, G. R. (1967). Hyperpyrexia during anaesthesia in a second member of a family, with associated coagulation defect due to increased intravascular coagulation. Canadian Anaesthetists' Society fournal, $14,183$.

Reiner, L., Konikoff, N., Altschule, M. D., Dammin, G. J., and Merrill, J. P. (1956). Idiopathic paroxysmal myoglobinuria. Archives of Internal Medicine, 87, 537.

Rowland, L. P., Fahn, S., Hirschberg, E., and Harter, D. H. (1964). Myoglobinuria. Archives of Neurology, 10, 537.

Scarpelli, D. G., Greider. M. H., and Frajola, W. J. (1963). Idiopathic recurrent rhabdomyolysis. American fournal of Medicine, 34, 426.

Schaar, F. E. (1955). Paroxysmal myoglobinuria. American Fournal of Diseases of Children, 89, 23.

Segar, W. E. (1959). Idiopathic paroxysmal myoglobinuria. Pediatrics, 23, 12.

Smith, R. F. (1968). Exertional rhabdomyolysis in naval officer candidates. Archives of Internal Medicine, 121, 313.

Spaet, T. H., Rosenthal, M. C., and Dameshek, W. (1954). Idiopathic myoglobinuria in man. Blood, 8, 881 .

Steers, A. J. W., Tallack, J. A., and Thompson, D. E. A. (1970). Fulminating hyperpyrexia during anaesthesia in a member of a myopathic family. British Medical fournal, 2, 341.

Stokes, W. (1953). Quoted by Acheson and McAlpine (1953).

Tavill, A. S., Evanson, J. M., Baker, S. B. de C., and Hewitt, V. (1964). Idiopathic paroxysmal myoglobinuria with acute renal failure and hypercalcemia. New England fournal of Medicine, 271, 283.

Thalassinos, N. C., Leese, B., Latham, S. C., and Joplin, G. F. (1970). Urinary excretion of phosphate in normal children. Archives of Disease in Childhood, 45, 269.

Verger, P., and Battin, J. J. (1962). La myoglobinurie paroxystique idiopathique. Archives Françaises de Pédiatrie, 19, 285.

Watson, R. J., and Ainbender, E. (1959). Quoted by Korein, Coddon, and Mowrey (1959).

Wheby, M. S., and Miller, H. S., Jr. (1960). Idiopathic paroxysmal myoglobinuria. American fournal of Medicine, 29, 599.

Wolfson, R., Yakulis, V., Coleman, R. D., and Heller, P. (1967) Studies on fetal myoglobin. Fournal of Laboratory and Clinical Medicine, 69, 729.

Correspondence to Dr. D. C. L. Savage, Department of Child Health, University of Dundee, 11 Dudhope Terrace, Dundee DD3 6HG, Scotland. 